\title{
The Effectiveness of the Interprofessional Collaboration (IPC) Program on The Attitude of Mothers and Health Cadres on Stunting at Puskesmas Karanganom Klaten Central Java Republic of Indonesia
}

\author{
Athanasia Budi Astuti ${ }^{1 \star}$, Sri Mulyanti ${ }^{1}$, Diyono ${ }^{2}$
}

\begin{abstract}
${ }^{1}$ Department of Nursing Politeknik Kesehatan Surakarta, INDONESIA
${ }^{2}$ Panti Kosala Institute of Health Sciences, Surakarta, INDONESIA

*Corresponding Author: athatika500@gmail.com
\end{abstract}

Citation: Astuti AB, Mulyanti S, Diyono. The Effectiveness of the Interprofessional Collaboration (IPC) Program on The Attitude of Mothers and Health Cadres on Stunting at Puskesmas Karanganom Klaten Central Java Republic of Indonesia. Electron J Gen Med. 2021;18(6):em328. https://doi.org/10.29333/ejgm/11315

\begin{tabular}{|c|c|}
\hline ARTICLE INFO & ABSTRACT \\
\hline Received: 5 Jul. 2021 & National stunting data in 2018 still reached $36 \%$. Stunting not only threatens the quality of human resources as \\
\hline Accepted: 31 Aug. 2021 & $\begin{array}{l}\text { the nation's next-generation but also harms socio-economically. The survey results show that one of the main } \\
\text { factors influencing stunting is the mother's attitude towards stunting. This study seeks to find a method to change } \\
\text { maternal attitudes to stunting through the Interprofessional Collaboration (IPC) program. This study aims to } \\
\text { determine the effectiveness of Interprofessional Collaboration on the attitudes of mothers and health cadres on } \\
\text { stunting. The experimental research was conducted with a quasi-experimental design (quasi-experimental pre- } \\
\text { test-post-test design) on } 90 \text { mothers with babies under two years of age. The treatment was in the form of an } \\
\text { Interprofessional Collaboration program (doctors, nurses, midwives, nutritionists, and sanitarians) for three } \\
\text { months. Data were analyzed by t-test. The results of data analysis showed that the average value of the mother's } \\
\text { attitude towards stunting changed from } 9.68 \text { to } 16.52 \text { ( } p=0.001 \text { ), the attitude of cadres increased from } 76.53 \text { to } \\
87.53 \text { ( } p=0.001 \text { ). Thus, Interprofessional Collaboration is effective in improving the attitude of mothers and health } \\
\text { cadres on stunting. }\end{array}$ \\
\hline
\end{tabular}

Keywords: stunting, interprofessional collaboration, health Cadre, malnutrition

\section{INTRODUCTION}

Currently, Indonesia is ranked 10th in the world's largest stunting rate. Even Indonesia is one of the countries with the highest stunting rate in Asia, behind Timor Leste, Laos, and Cambodia. Stunting in Indonesia was recorded at 7.8 million out of 23 million children under five with $35.6 \%$ [1-4]. A total of $18.5 \%$ of the very short category and $17.1 \%$ of the short category. This has also resulted in WHO establishing Indonesia as a country with poor nutritional status. The prevalence of stunting in Indonesia over the last ten years shows no change, so it needs to be addressed immediately. The incidence of stunting in Indonesia still reaches 29.9\% [5-8]. Other nutritional problems related to stunting are anemia in pregnant women (37.1\%), low birth weight babies (10.2\%), underweight or wasting infants $(10.1 \%)$, and anemia in toddlers. Only $48.6 \%$ of children under five do not suffer from nutritional disorders [912]. Another factor for stunting is the individual level, caregivers, poor diet, and low maternal education [13-17].

The impact of stunting occurs in childhood and can continue during subsequent growth and development and even into adulthood Physically and psychologically [18-21]. If this condition is not addressed immediately, the demographic bonus that the Indonesian people should enjoy will turn into a disaster because many future generations are stunted [22,24]. The Indonesian government has been trying to control and reduce the prevalence of stunting since 2005. However, in reality, the majority of stunting has not shown a decline in the last five years. On the contrary, it tends to increase or stagnate. Specifically, for stunting, the government has issued specific nutrition intervention programs and sensitive nutrition interventions. However, these programs have not reduced stunting prevalence according to the set targets [25-27]. Therefore, it is necessary to find the root of the problems that hinder the achievement of these targets.

Training such as workshops and seminars can be used to approach [28]. In this study, researchers seek to find a new strategy to prevent stunting, namely the Interprofessional Collaboration (IPC), whether it can change the attitudes of mothers and health cadres about stunting. Interprofessional Collaboration is a good and mutually beneficial collaboration between two or more organizations or professions to achieve specific goals $[29,30]$. This study aims to determine the effectiveness of the Interprofessional Collaboration (IPC) program on the attitudes of mothers and health cadres about stunting. 
Table 1. Characteristics of mother and early childhood $(n=90)$

\begin{tabular}{lcc}
\hline \multicolumn{1}{l}{ Category } & f & $\%$ \\
\hline Mother's Age & & \\
\hline $20-30$ & 0 & 52.22 \\
\hline $31-40$ & 0 & 41.11 \\
\hline $41-50$ & 5 & 6.67 \\
\hline Mother's Education & \\
\hline Basic Education & 9 & 10.00 \\
\hline Middle Education & 76 & 84.44 \\
\hline High Education & 5 & 5.56 \\
\hline Mother's Profession & 5.56 \\
\hline Work & 5 & 94.44 \\
\hline Housewife & 95 & \\
\hline Mex of Baduta & & \\
\hline Fimale & 42 & 53.33 \\
\hline & 48 &
\end{tabular}

Table 2. Description of health cadre

\begin{tabular}{ccc}
\hline \multicolumn{1}{l}{ Category } & f & $\%$ \\
\hline Cadre's Age & & \\
\hline $20-30$ & 2 & 06.67 \\
\hline $31-40$ & 19 & 63.33 \\
\hline $41-50$ & 9 & 30.00 \\
\hline Cadre's Education & \\
\hline Basic Education & 3 & 10.00 \\
\hline Middle Education & 25 & 83.33 \\
\hline High Education & 2 & 6.67 \\
\hline Mother's Profession & \\
\hline Work & 10 & 33.33 \\
\hline Housewife & 20 & 66.67
\end{tabular}

\section{METHOD}

To meet the aim of the study, the experimental study was conducted using a quasi-experimental pre-test post-test design on 90 mothers with babies under two years (early childhood) and 30 health cadres. The treatment was in an Interprofessional Collaboration program (doctors, nurses, midwives, nutritionists, and sanitarians) for three months. Data were analyzed by t-test. The research was carried out in the working area of Karanganom Public Health Center, Klaten Regency, Central Java.

\section{RESULT}

\section{Characteristics of Respondents}

The characteristics of respondents in the study can be seen in Table 1.

Table 1 demonstrates the mother's age in the category of 20-30 years at $52.22 \%$. The smallest number in the age group 41-50 years with $6.67 \%$. The description of the last education level of the mother, the most is secondary education as much as $84.44 \%$ while the lowest is at the higher education level, namely $5.56 \%$. Most mothers do not work like housewives, namely $94.44 \%$, while those who work are only $5.56 \%$. The gender of baduta is almost evenly distributed, namely men as much as $46.67 \%$ and more women, namely $53.33 \%$.

\section{Attitude towards Stunting}

Table 3 provides information before treatment (IPC program) for the category of poor mothers' attitudes towards
Table 3. Description of the effect of the IPC Program on the Attitude of Baduta Mothers on Stunting

\begin{tabular}{cccccc}
\hline \multirow{2}{*}{ Category } & \multicolumn{2}{c}{ Pre } & \multicolumn{2}{c}{ Post } & \multirow{2}{*}{$\begin{array}{c}\text { t-test } \\
\text { Sig.2 tailed }\end{array}$} \\
\cline { 2 - 5 } & f & $\%$ & f & $\%$ & \\
\hline Good & 51 & 56.67 & 84 & 93.33 & \\
\hline Poor & 39 & 43.33 & 6 & 6.67 & \\
\hline Amount & 90 & 100 & 90 & 100 & \\
\hline
\end{tabular}

Table 4. Description of the effect of the IPC Program on the Attitude of Health Cadres on Stunting

\begin{tabular}{|c|c|c|c|c|c|}
\hline \multirow{2}{*}{ Category } & \multicolumn{2}{|c|}{ Pre } & \multicolumn{2}{|c|}{ Post } & \multirow{2}{*}{$\begin{array}{c}\text { t-test } \\
\text { Sig.2 tailed }\end{array}$} \\
\hline & $f$ & $\%$ & $f$ & $\%$ & \\
\hline Good & 12 & 40.00 & 28 & 93.33 & \multirow{3}{*}{$p=0.001$} \\
\hline Poor & 18 & 60.00 & 2 & 6.67 & \\
\hline Amount & 30 & 100 & 30 & 100 & \\
\hline
\end{tabular}

stunting, which was less as much as $43.33 \%$, and after the implementation of the IPC program, it decreased to $6.67 \%$ and well increased from 56.67 to $93.33 \%$. The results of the t-test $p=0.001$ prove that there is a significant difference between before IPC and after IPC.

\section{Cadre's Attitude on Stunting}

Table 4 provides information before treatment (IPC program) that the attitude of health cadres towards stunting was mostly in the less category, namely $60.00 \%$, after the implementation of the IPC program it decreased to only $6.67 \%$, while the good ones increased from $40 \%$ to $93.33 \%$. The results of the t-test $p=0.001$ proved that there was a significant difference between before IPC and after IPC, and it can be concluded that the IPC program is effective in changing the attitude of health cadres on stunting.

\section{DISCUSSION}

\section{The Effectiveness of IPC Against Attitudes About Stunting}

Human behaviour is not only influenced by knowledge but also strongly influenced by attitudes. A positive perception or attitude towards an object or event will significantly influence the formation of behaviour. The IPC program, in principle, seeks to increase cooperation between health professions so that every health professional has the same perception and concern for stunting. This same understanding and concern can help the community assess and give opinions about stunting to change people's perceptions or attitudes. The work process in Interprofessional Collaboration in principle must meet at least three components or criteria. Must involve experts with different fields of expertise who can work reciprocally smoothly. Group members must be firm and willing to cooperate. Third, the group must provide services whose uniqueness results from combining each team member's views and expertise.

As shown in Table 4, the study results prove that before treatment (IPC program), the category of baduta mother's attitude towards stunting was $43.33 \%$ and after the IPC program implementation decreased to $6.67 \%$ and good increased from 56.67 to $93.33 \%$. Statistical test with SPSS series 18 gave the mean attitude pre-treatment 9.67 , mean post or after treatment 16.52 , with mean differences -6.84 , and sig- 2 tailed $\mathrm{p}=0.001$ proves that the IPC program can significantly improve the attitudes of mothers of children 
under two years old. Against stunting. A good and positive attitude towards stunting will make it easier for health workers to invite mothers under two to work together to eliminate stunting risk factors in their families. In the IPC program, as many as five health professions, namely doctors, nurses, midwives, nutrition, and sanitarians, coordinate and work together to provide health education or counselling on stunting following their respective competencies and authorities. In this study, counselling was carried out directly by resource persons from doctors, nurses, midwives, nutrition, and environmental health. Counselling was conducted once, with small groups, where 90 respondents were divided into three groups of 30 respondents each. Although the material given for each group is different, because the materials and media have been made the same, it has been proven to increase the knowledge of under-tax mothers about stunting and undernutrition.

Through this health education, it is hoped that it can increase the knowledge of under-tax mothers about stunting and nutrition in under-fives. Good knowledge, directly or indirectly, can influence or change the behavior of mothers under two in stunting prevention. This is by the previous theoretical concept where stunting can be prevented by eliminating risk factors that can cause stunting in mothers, babies, and the environment [17-22]. The results of this study also further strengthen the findings of previous studies where the causes or risk factors for stunting vary widely, which are closely related to the educational status and culture of the community [28-30]. The data from this research Kemendesa PDTT (2018) [17], shows that the education level of most respondents is secondary education (Junior High School/Senior High School). However, intense health counselling can increase the understanding of under-tax mothers regarding stunting and nutrition of under-fives. Parental education and socioeconomic factors affect energy and protein intake in under-fives who have edited [13,25].

Compared to other factors such as disease history and family education, socio-economic conditions are the main determinants of the risk of stunting $[23,24]$. The research results by $[8,24,25]$, the IPC Program focuses not only on increasing public knowledge, especially mothers of underfives, but in this study, there are also efforts to increase the knowledge and understanding of health cadres about stunting and child nutrition. Health cadres are a community institution that has a major role in guiding and assisting under-five mothers in stunting prevention. This follows the concept of Interprofessional Collaboration which emphasizes good and mutually beneficial cooperation between two or more organizations or professions to achieve specific goals. The relationship includes a commitment to a standard definition of relationship and goals, shared structure and responsibilities, shared authority and accountability for success, and resources and rewards [12].

\section{The Effectiveness of IPC on the Attitude of Health Cadres on Stunting}

According to the Regulation of the Minister of Health of the Republic of Indonesia No. 25 of 2014 concerning Child Health Efforts, health cadres are people who are chosen by the community and trained to handle individual or community health problems and work in places related to the provision of health services in a very close relationship with the health service provider.
Health cadres are community members who voluntarily become health workers to assist in health improvement programs [18]. Health cadres are elected by the community, work by and for the community. In practice, cadres have an important role in efforts to eradicate stunting. This is because the cadres meet and interact with mothers who have babies almost every day. Health cadres are the first referrals to seek information related to health problems, including stunting. One of the factors that influence the incidence of stunting is the cultural factor of the community, especially mothers. The community firmly believes culture greatly determines the mindset and behaviour of people [23]. In Indonesia, this cultural factor is very important, especially in rural areas. The average mother behaves according to hereditary culture. The role of cadres is very important in changing this perception and culture because the cadres are chosen by the community themselves so that a sense of trust has emerged. This trust in cadres is constructive in changing mothers' attitudes towards stunting. Changing attitudes is not straightforward, it requires continuity of knowledge provision, and the main thing is a source of information that comes from community members whom mothers and families trust.

One of the efforts to prevent and treat stunting is to carry out specific nutrition interventions and sensitive nutrition interventions on the target of the first 1,000 days of a child's life up to the age of 6 years $[6,15,17]$. This intervention requires continuous supervision and assistance and continuous and scheduled monitoring. This monitoring requires the role of health cadres who are directly close to the community. At least once a month, the baby will be taken to the Posyandu, where the health cadres can monitor and evaluate the baby's growth and development. Health cadres have an important role in intervention in children aged $0-6$ months by encouraging early breastfeeding initiation (breastfeeding with breast milk/colostrum) and encouraging exclusive breastfeeding. Interventions for breastfeeding mothers and children aged 723 months can be carried out by encouraging continued breastfeeding until the age of 23 months accompanied by complementary feeding, providing deworming medicine, providing zinc supplementation, fortifying iron into food, providing protection against malaria [28-30]. Provide complete immunization, and do prevention and treatment of diarrhea. Cadres also have an important role in providing and ensuring maternal access to clean water, providing and ensuring access to sanitation, fortifying foodstuffs, providing access to health and family planning (KB) services, and providing National Health Insurance (JKN) against stunting [30]. These interventions will not work correctly without cooperation or collaboration between health professionals in direct contact with health cadres.

In this study, subjectively, health cadres feel more comfortable and understand more about stunting because all health professions continuously provide information to health cadres about stunting control programs. Furthermore, through the IPC program, because each health profession carries out all stunting prevention programs following their respective job descriptions and authorities so that the knowledge of health cadres increases and changes the attitude of health cadres, from a less concerned attitude to more caring, so that it can assist the process of giving nutrition in infants. The data analysis results showed that the cadres' attitude increased from 76.53 to 87.53 , with a P-value of 0.001 , proving that the IPC program effectively changed the mother's attitude from bad to 
good or caring. This change in attitude encourages cadres to be more concerned in guiding mothers in providing nutrition or nutrition to babies because this nutrition behaviour is one of the main factors in increasing the risk of stunting.

The results of this study are in line with studies on stunting in several other countries, which provide evidence that government policies or policies regarding education for pregnant women and immunization are also determinants of stunting [1]. In addition, inadequate nutrition for children under five significantly affects stunting $[7,9]$. nutritional intake in toddlers greatly affects stunting [22]. Non-stunting toddlers have high intakes of energy, protein, Fe, Zink, and psychosocial stimulation, as well as a good development [21]. Furthermore, dietary factors in toddlers are a risk factor for stunting, where reduced dietary diversity is a strong predictor of stunting [5]. Therefore, the inclusion of various food groups in complementary foods may be important to improve the nutritional status of children to prevent stunting [29].

\section{CONCLUSION}

One of the essential nutrients in children under five is breast milk (Mother's Milk). The study results showed a relationship between the birth length of toddlers, history of exclusive breastfeeding, family income, mother's education, and maternal nutrition knowledge on the incidence of stunting in toddlers. Therefore, integrated and multisectoral programs are needed to increase family income, education, nutrition knowledge, and exclusive breastfeeding in reducing stunting [11-17]. low family economic status is a significant risk factor for stunting in toddlers aged 2-3 years [4,15]. Children with low family economic status are 4.13 times more likely to experience stunting, while the level of education does not have a significant relationship with the risk of stunting. These studies prove that the pattern of nutrition in infants is one of the determinants of success in preventing stunting because poor nutrition in infants greatly affects the growth and development of the baby's body length.

The IPC program effectively influences the way mothers think and act. It is characterized by a significant difference in the actions and attitudes of Health cadres before and after IPC. With the change in the pattern of thinking and action, the mother under two will pay more attention to the health of the babies, such as providing food with adequate nutrition to avoid stunting. For the future studies. It seems vital to conduct regular counselling conducted by doctors, nutritionists, midwives, and nurses to the community to understand stunting from an early age.

Author contributions: All authors have sufficiently contributed to the study, and agreed with the results and conclusions.

Funding: No funding source is reported for this study.

Declaration of interest: No conflict of interest is declared by authors.

\section{REFERENCES}

1. Abuya BA, Onsomu EO, Kimani JK, Moore D. Influence of maternal education on child immunization and stunting in Kenya. Matern Child Health J. 2011;15(8):1389-99. https://doi.org/10.1007/s10995-010-0670-z PMid:20848172
2. Aguayo VM, Menon P. Stop stunting: Improving child feeding, women's nutrition and household sanitation in South Asia. Maternal and Child Nutrition. 2016;12:3-11. https://doi.org/10.1111/mcn.12283 PMid:27187906 PMCid: PMC5084809

3. Alam MA, Richard SA, Fahim SM, Mahfuz M, Nahar B, et al. Impact of early-onset persistent stunting on cognitive development at 5 years of age: Results from a multi-country cohort study. PLoS ONE. 2020;15(1):e0227839. https://doi.org/10.1371/journal.pone.0227839 PMid:31978156 PMCid:PMC6980491

4. Ali A. Current status of malnutrition and stunting in Pakistani children: What needs to be done? J Am Coll Nutr. 2021;40(2):180-92. https://doi.org/10.1080/07315724.2020. 1750504 PMid:32275484

5. Amaral MM, Herrin WE, Gulere GB. Using the Uganda National Panel Survey to analyze the effect of staple food consumption on undernourishment in Ugandan children. BMC Public Health. 2017;18(1):32. https://doi.org/10.1186/ s12889-017-4576-1 PMid:28724425 PMCid:PMC5518155

6. Ardiana A, Afandi AT, Masaid AD, Rohmawati N. Utilization of agricultural products for the management and prevention stunting through empowering health Cadres in Jember District. Darmabakti Cendekia: Journal of Community Service and Engagements. 2020;2(1):9. https://doi.org/10.20473/dc.v2.i1.2020.9-14

7. Banerjee K, Dwivedi LK. Disparity in childhood stunting in India: Relative importance of community-level nutrition and sanitary practices. PLoS ONE. 2020;15(9 September): e0238364. https://doi.org/10.1371/journal.pone.0238364 PMid:32870942 PMCid:PMC7462311

8. Bloem MW, de Pee S, Hop LT, Khan NC, Laillou A, Minarto, Moench-Pfanner R, Soekarjo D, Soekirman Solon JA, Theary C, Wasantwisut E. Key strategies to further reduce stunting in Southeast Asia: lessons from the ASEAN countries workshop. Food Nutr Bull. 2013;34(2Suppl):S8S16. https://doi.org/10.1177/15648265130342s103 PMid: 24049992

9. Danaei G, Andrews KG, Sudfeld CR, Fink G, et al. Risk Factors for Childhood Stunting in 137 Developing Countries: A Comparative Risk Assessment Analysis at Global, Regional, and Country Levels. PLoS Medicine. 2016;13(11):e1002164. https://doi.org/10.1371/journal.pmed.1002164 PMid:27802277 PMCid:PMC5089547

10. Dewey KG, Begum K. Long-term consequences of stunting in early life. Matern Child Nutr. 2011;7(SUPPL. 3):5-18. https://doi.org/10.1111/j.1740-8709.2011.00349.x PMid:21929633 PMCid:PMC6860846

11. Ekholuenetale M, Barrow A, Ekholuenetale CE, Tudeme G. Impact of stunting on early childhood cognitive development in Benin: evidence from Demographic and Health Survey. Egyptian Pediatric Association Gazette. 2020;68(1):31. https://doi.org/10.1186/s43054-020-00043-x

12. Green BN, Johnson CD. Interprofessional collaboration in research, education, and clinical practice: working together for a better future. J. Chiropr. Educ. 2015;29(1):110. https://doi.org/10.7899/JCE-14-36 PMid:25594446 PMCid:PMC4360764

13. Hernández-Vásquez $\mathrm{A}$, Pisfil-Benites $\mathrm{N}$, Vargas-Fernández R, Azañedo D. Nutritional status and effective verbal communication in Peruvian children: A secondary analysis of the 2019 demographic and health survey. PLoS ONE. 2021;16(2 February):e0246542. https://doi.org/10.1371/ journal.pone.0246542 PMid:33600423 PMCid:PMC7891687 
14. Izza N, Purnomo W, Mahmudah. Factors affecting the occurrence of stunting in indonesia. Indian J Public Health Res Dev. 2019;10(10):1845-50. https://doi.org/10.5958/0976-5506.2019.03114.0

15. Jumintono, Suyatno, Zuhaery M, Said H, Azman MNA Vocational education principal of leadership: A case study in East Nusa. Int J Soc Sci Res. 2018;6:825-31. https://doi.org/https://doi.org/10.32861/jssr.spi6.825.81

16. Krishna A, Mejía-Guevara I, McGovern M, Aguayo VM, Subramanian SV. Trends in inequalities in child stunting in South Asia. Matern Child Nutr. 2018;14(S4):e12517. https://doi.org/10.1111/mcn.12517 PMid:29048726 PMCid: PMC6519254

17. Mejia CR, Sulca PA, Hernani-Salazar L, Ricaldi-Asto L, Rojas MA, Hernández-Arriaga G, Tovani-Palone MR, BuesoPineda L. Association of nutritional status and anemia with multi-micronutrient supplementation in young children in Peru. Electron J Gen Med. 2019;16(5):em163. https://doi.org/10.29333/ejgm/114662

18. Millward DJ. Nutrition, infection and stunting: The roles of deficiencies of individual nutrients and foods, and of inflammation, as determinants of reduced linear growth of children. Nutr Res Rev. 2017;30(1):50-72. https://doi.org/10.1017/S0954422416000238 PMid:28112064

19. Ponum M, Khan S, Hasan O, Mahmood MT, et al. Stunting diagnostic and awareness: Impact assessment study of sociodemographic factors of stunting among school-going children of Pakistan. BMC Pediatrics. 2020;20(1):232. https://doi.org/10.1186/s12887-020-02139-0 PMid:32429876 PMCid:PMC7236201

20. Purwandari ES, Estiningtyas Sakilah Adnani Q, Yuli Astutik R. Analysis of maternal age at married, number of children, history of breastfeeding, mother's education and high risk of pregnancy with incidence of stunting in children under five-years. Women, Midwives and Midwifery. 2021;1(1):2130. https://doi.org/10.36749/wmm.1.1.21-30.2021

21. Rah JH, Akhter N, Semba RD, Pee SD, Bloem MW, Campbell AA, Moench-Pfanner R, Sun K, Badham J, Kraemer K. Low dietary diversity is a predictor of child stunting in rural Bangladesh. Eur J Clin Nutr. 2010;64(12):1393-8. https://doi.org/10.1038/ejcn.2010.171 PMid:20842167

22. Rah Jee Hyun, Cronin, AA, Badgaiyan B, Aguayo V, Coates S, Ahmed $S$. Household sanitation and personal hygiene practices are associated with child stunting in rural India: A cross-sectional analysis of surveys. BMJ Open.2015;5(2): e005180. https://doi.org/10.1136/bmjopen-2014-005180 PMid:25678539 PMCid:PMC4330332
23. Sari YW, Wirjatmadi B, Setyaningtyas SW. The Relation Between Macronutrient Adequency Level Mother's Personal Hygiene, Environmental Sanitation and Diarrhea with Stunting Incidences Among Childern Aged 24-59 Months. Preventif: Jurnal Kesehatan Masyarakat. 2020;11(2):94-104.

https://doi.org/10.22487/preventif.v11i2.114

24. Simbolon D, Suryani D, Yorita E. Prediction model and scoring system in prevention and control of stunting problems in under five-year-olds in Indonesia. Jurnal Kesehatan Masyarakat. 2019;15(2):160-70. https://doi.org/10.15294/kemas.v15i2.13415

25. Supeni S, Nurati DE, Sufa FF, Jumintono. Instilling values of javanese leadership culture for primary school principal. Opción. 2019;35(21):1427-44. Available at: https://produc cioncientificaluz.org/index.php/opcion/article/view/24781

26. Teshome B, Kogi-Makau W, Getahun Z, Taye G. Magnitude and determinants of stunting in children underfive years of age in food surplus region of Ethiopia: The case of West Gojam Zone. Ethiop J Health Dev. 2010;23(2):98-106. https://doi.org/10.4314/ejhd.v23i2.53223

27. Utami AD, Indarto D, Lanti Y, Dewi R. The effect of nutrient intake and socioeconomic factor toward stunting incidence among primary school students in Surakarta. Journal of Epidemiologi and Public Health. 2017;2(1):1-10. https://doi.org/jepublichealth.2017.02.01.01

28. Wicaksono RA, Arto KS, Saragih RAC, Deliana M, Lubis M, Batubara JRL. Comparison of growth diagrams of Indonesian children to 2006 world health organization growth standards in diagnosing stunting. Paediatrica Indonesiana (Paediatrica Indonesiana). 2020;60(2):95-100. https://doi.org/10.14238/pi60.2.2020.95-100

29. Yarmaliza Y, Farisni TN, Fitriani F. The Influence of Mother Characteristics on giving tempe broth as an effort prevention of stunting in toddler. The Indonesian Journal of Public Health. 2019;6(2):49. https://doi.org/10.35308/jkesmas.v6i2.1185

30. Zavareh MSA, Hasani M, Darabi M, Mirzaei A, Khorshidi A, Saeidi A, Momeni K, Jalilian M. Growth indicators and nutritional supplement evaluation in 6-12 months year old children's: A perspective from Ilam. ElectronJ Gen Med. 2018;15(3):em17. https://doi.org/10.29333/ejgm/85494 